\section{Stem-injection of herbicide for control of Ailanthus altissima (Mill.) Swingle: a practical source of power for drilling holes in stems}

\author{
Emilio Badalamenti, Tommaso La Mantia
}

\begin{abstract}
Ailanthus altissima is a well-known invasive tree in many parts of the world showing an outstanding ability to establish within woodlands and other less-disturbed habitats. Previous studies have reported that control of this species is very difficult because of its strong resprouting. Indeed, effective control can be achieved only by mechanical treatment followed by the application of a systemic herbicide. Operating drills or saws and other mechanical equipment require electric power supply which is not readily available in many invaded sites, notably shrubslands and woodlands. In two study sites, we evaluated control obtained by glyphosate through a stem-injection technique and compared two sources of power for the electric drill used. More than $90 \%$ of the glyphosate-treated trees in this study appeared to be dead just 1 month after treatments, and a car battery plus inverter was the most practical electrical source for drilling stems in the field.
\end{abstract}

Keywords: Invasive Alien Species, Management Strategies, Control Technique, Glyphosate

\section{Introduction}

Invasive species are recognized as one of the main threats to European forests, especially at regional level (Requardt et al. 2009). One of the most dangerous alien tree all around the world is Ailanthus altissima (Mill.) Swingle (hereafter A. altissima), which is particularly widespread in temperate and Mediterranean regions (Kowarik \& Säumel 2007). The species was introduced from China to Europe in the second half of the $18^{\text {th }}$ century, and was initially used as an ornamental plant but later also for the urban forestation and for erosion control of steep slopes (Badalamenti et al. 2012). Nowadays it is considered a major invader in many

$\square$ DEMETRA Department, University of Palermo, v.le delle Scienze, Ed. 4, Ingr H, I90128 Palermo (Italy)

(a) Tommaso La Mantia

(tommaso.lamantia@unipa.it)

Received: Jul 19, 2012 - Accepted: Nov 15, 2012

Citation: Badalamenti E, La Mantia T, 2013. Stem-injection of herbicide for control of Ailanthus altissima (Mill.) Swingle: a practical source of power for drilling holes in stems. iForest 6: 123-126 [online 2013-0305] URL: http://www.sisef.it/iforest/ contents?id=ifor0693-006

Communicated by: Roberto Tognetti parts of the United States (Anonymous 2012), in most of temperate and Mediterranean Europe (Lambdon et al. 2008), and throughout Italy (Celesti-Grapow et al. 2010) including Sicily (Badalamenti et al. 2012). A. altissima has a wide ecological range, due to its very high growth rate, effective reproductive and dissemination systems, and general lack of natural enemies (Kowarik \& Säumel 2007) in its secondary range. For these reasons A. altissima can compete effectively against the native flora in disturbed and degraded sites, such as roadsides and other urban areas, including archaeological sites (Celesti-Grapow \& Blasi 2004). A. altissima has also invaded natural habitats, along forest edges and open gaps (Knapp \& Canham 2000), especially in the presence of anthropic disturbance. For instance, occasional fires favors A. altissima spread because of its impressive capacity of resprouting by injured stumps and superficial roots (Meggaro \& Vilà 2002, DiTomaso et al. 2006). In addition to damaging ecosystems, A. altissima causes serious problems for forest management (Meggaro \& Vilà 2002, Constán-Nava et al. 2010) because it competes directly with the woody species of silvicultural interest and makes forest utilization more difficult and expensive. Under favorable conditions, $A$. altissima can form almost pure stands, which obviously reduce biodiversity and change the abiotic characteristics of the ecosystems, including the chemical and physical characteristics of the soil (Vilà et al. 2006). Within only a few years after its initial invasion and in the absence of appropriate control, this fast-growing tree makes the recovery and restoration of native vegetation extremely difficult. For these characteristics, A. altissima is considered a fast-growing and contaminationresistant species (Capuana 2011).

The dramatic ecological consequences of A. altissima invasion have long been recognized especially in the Mediterranean basin, where it has been recently included in the EPIDEMIE project ("Exotic Plant Invasions: Deleterious Effects on Mediterranean Island Ecosystems"), supported by the European Commission (Traveset et al. 2008, Vilà et al. 2008, Affre et al. 2010). One of the main reason why $A$. altissima is a successful invader in Mediterranean-type regions is its ability to cope with summer drought. In particular, this species is able to reduce water loss through a marked reduction in stomatal conductance and in root hydraulic conductivity (Graves et al. 1991, Trifilò et al. 2004). Like other Mediterranean island ecosystems, Sicily has experienced substantial $A$. altissima invasion, and despite this its establishment and spread process have seldom been documented or studied. In particular this tree is able to invade a wide range of pedo-climatic environments and is increasingly common throughout the island in natural and semi-natural habitats, from sea level up to $1300 \mathrm{~m}$ a.s.l. (Badalamenti et al. 2012).

Because of the serious damage caused by A. altissima worldwide, many control trials have been carried out in many different regions, including Mediterranean Europe, the United States, and Canada (Burch \& Zedaker 2003, Meloche \& Murphy 2006, DiTomaso \& Kyser 2007, Constán-Nava et al. 2010, Bowker \& Stringer 2011). These field experiences have clearly demonstrated that the eradication of A. altissima is extremely difficult and expensive, as mechanical treatment alone (cutting the trunk at the root collar or girdling the tree) does not kill the tree, but rather stimulates vigorous resprouting from the remaining trunk and roots (Burch \& Zedaker 2003, Basnou \& Vilà 2009, Kowarik \& Säumel 2007). Even a "double-cut stump treatment" performed each year for 5 consecutive years failed to significantly reduce the ability to resprout (Constán-Nava et al. 2010). Only the application of herbicides combined with physical treatment has effectively controlled regrowth and significantly reduced the presence of $A$. altissima in invaded areas (Burch \& Zedaker 2003, Meloche \& Murphy 2006, DiTomaso \& Kyser 2007, Constán-Nava et al. 2010, Bowker \& Stringer 2011). For example, the combined application of heavy mechanical treatments and herbicides suppressed A. al- 
tissima in Carrascal de la Font Roja Natural Park (Alicante Province, SE Spain), where the first signs of recovery by the natural vegetation were observed 5 years after the treatments were applied (Constán-Nava et al. 2010).

One of the herbicides that has given satisfactory control of A. altissima is glyphosate, so that it is considered "a mainstay of woody plant vegetation management" (Blair et al. 2006). In our study we used this chemical, and we attempted to identify a practical way to control A. altissima in woodlands and other remote areas where main electricity is not easily accessed.

\section{Materials and methods}

\section{The study sites}

The trials were carried out at two sites near Palermo (NW Sicily) at altitudes between 50 and $100 \mathrm{~m}$ a.s.l. and over surfaces of about $500 \mathrm{~m}^{2}$. The first site was an abandoned orchard in a suburban environment $\left(38^{\circ} 06^{\prime}\right.$ 28.91 " N, $13^{\circ} 19^{\prime} 24.91$ ” E), and the second site was a semi-natural community afforested with Pinus halepensis Mill (38 $8^{\circ} 05^{\prime} 40.82$ ' $\mathrm{N}, 13^{\circ} 15^{\prime} 41.32^{\prime \prime}$ E). Both sites have been heavily invaded by A. altissima and share a typical Mediterranean climate, with about $600 \mathrm{~mm}$ of rainfall per year, concentrated during the coldest months. The average annual temperature is $19{ }^{\circ} \mathrm{C}$ (Drago et al 2002). Despite similar climatic conditions, the two sites are ecologically different because of differences in management. At the first site, the abandonment of cultivation has enabled the rapid invasion by $A$. altissima, and although some orchard trees are still evident, A. altissima is the dominant species At the second site, the presence of a simplified forest ecosystem, due to frequent human disturbance, along with the absence of control interventions, have favored A. altissima spread. This non-native tree is able to establish quickly in forest clearings and along forest borders, from which it gradually spreads into adjacent forested areas.

\section{Treatments}

Experiments were carried out in early $\mathrm{Au}$ gust, late in the vegetative growth of $A$. altissima, when an injected herbicide is readily translocated to the roots (Hoshovsky 1988) In each site a total of 40 trees, randomly chosen, were treated with undiluted glyphosate $\left(\right.$ Myrtos $^{\circledR} 360$ SL, NUFARM Italia srl, Milan - $360 \mathrm{~g}^{-1} \mathrm{t}^{-1}$ ) that was injected into holes drilled into the stems. One $\mathrm{ml}$ of the herbicide was used when DBH (diameter at breast height) of trees was lower than $8 \mathrm{~cm}$ (20 trees per site), while $2 \mathrm{~mL}$ were used when DBH was larger than $8 \mathrm{~cm}(20$ trees per site). The average DBH of the stand was $14 \mathrm{~cm}$. Trunk holes were located $1 \mathrm{~m}$ above the soil surface, about $5 \mathrm{~cm}$ deep into the

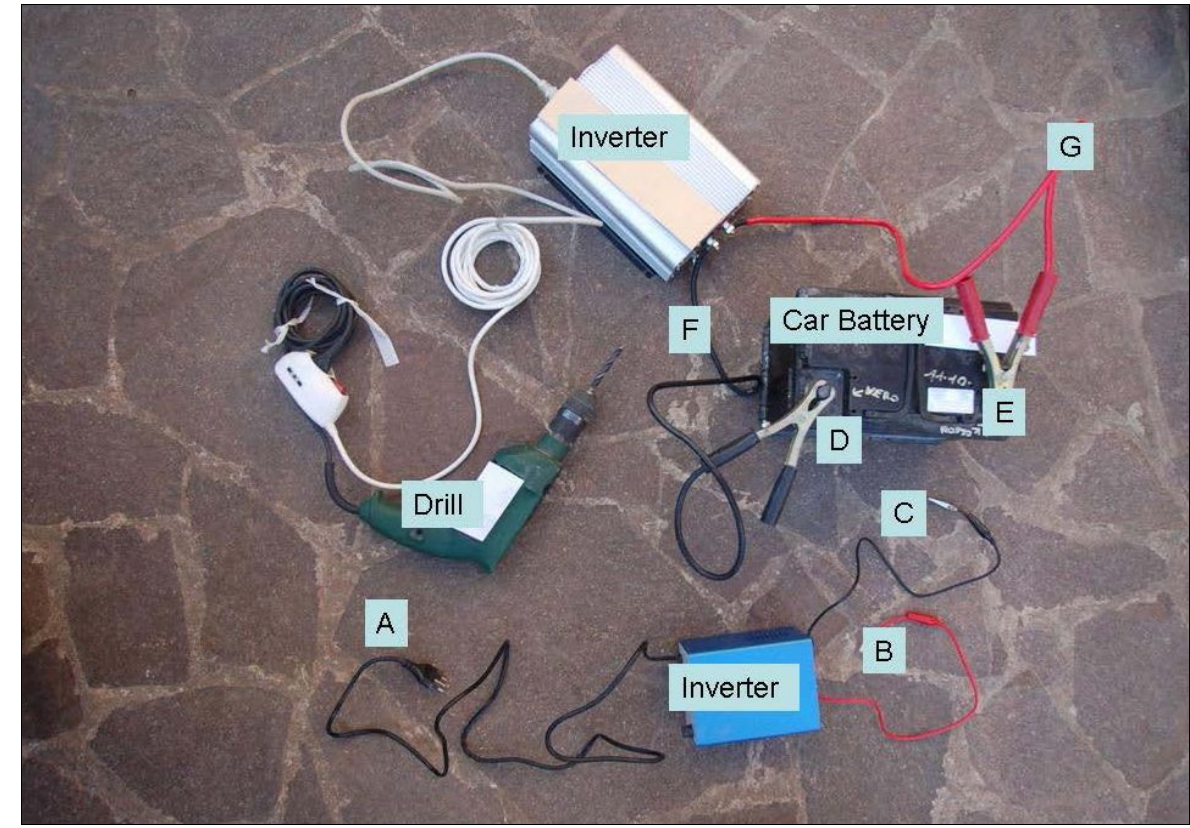

Fig. 1 - Recommended equipment for drilling for stem-injection technique. Before the battery is taken to the field, it is charged with the blue inverter, which is connected to the elec tricity grid via a plug $(\mathrm{A})$ and connected to the battery via the positive and negative poles (B and $\mathrm{C}$, which are not connected to the battery in the figure). In the field, the charged battery feeds a second inverter via cables ( $\mathrm{F}$ and $\mathrm{G}$ - via the positive and negative poles $\mathrm{D}$ and $\mathrm{E}$ ), and the inverter supplies power via another cable to the drill.

stem or trunk. One hole was drilled into each tree. We also compared drill bits $\left(\right.$ Krino ${ }^{\circledR}$, Italy) with a diameter ranging from 8 to 10 $\mathrm{mm}$. Drilling a few holes, we preli-minarily verified that $10-\mathrm{mm}$ diameter drill bits are best suited to put the fixed rate of glyphosate.

The herbicide was injected with a plastic syringe. The injected holes were pointed downward (at $45^{\circ}$ ), and after injection each hole was sealed with a wound-sealing compound in order to reduce the chance of herbicide spreading from the application site to the surrounding vegetation. The canopy of the treated trees was visually assessed about 1 month (September 2011, short-term evaluation) and 8 months (April 2012, long-term evaluation) after treatments.

The control techniques applied in the field

The availability of main electricity in remote areas is a recurring problem, and we therefore compared a drill with rechargeable battery (cordless drill, Black \& Decker ${ }^{\mathbb{B}}$ ),

Tab. 1 - Dead tree mortality of Ailanthus altissima after treatment with glyphosate.

\section{Study sites}

Dead trees after Dead trees after one month eight months

Abandoned orchards. Trees with $\mathrm{DBH}<8 \mathrm{~cm}$

Abandoned orchards. Trees with DBH $>8 \mathrm{~cm}$

Pinus halepensis afforestation. Trees with $\mathrm{DBH}<8 \mathrm{~cm}$

Pinus halepensis afforestation. Trees with DBH $>8 \mathrm{~cm}$ and a car battery $\left(12 \mathrm{~V}, 70 \mathrm{Ah}\right.$, Unienergy ${ }^{\circledR}$, Italy) plus one car battery charger (Life ${ }^{\circledR}$, Italy), and one inverter (GBC, Italy) to transform a $12 \mathrm{~V} \mathrm{CC}$ to $220 \mathrm{~V} \mathrm{AC}$, as to connect the car battery to the drill - see Fig. 1). In the first site 30 stems were drilled with power system one and 10 with the power system two, while in the second site we applied only the power system two. We took into account not only the working speed, but also technical and operational feasibility of these two possible sources of power.

\section{Results}

In both studied areas more than $90 \%$ of the glyphosate-treated $A$. altissima trees appeared to be dead one month after treatments and these results were confirmed 8 months later (Tab. 1). Non-treated Ailanthus trees and non-target woody species within the sampling areas remained healthy.

Comparing the two drilling systems adopted in the present study, we found that cordless drill usually works for no more than one hour, allowing the treatment of about 30 
Tab. 2 - Comparison between three electrical sources used to power the drill.

\begin{tabular}{lccc}
\hline \multicolumn{1}{c}{ Parameters } & $\begin{array}{c}\text { Cordless } \\
\text { drill }\end{array}$ & $\begin{array}{c}\text { Drill } \\
\text { (with car battery) }\end{array}$ & $\begin{array}{c}\text { Electrical } \\
\text { drill }\end{array}$ \\
\hline $\begin{array}{l}\text { Practical efficiency } \\
\text { (in woods or in mountains) }\end{array}$ & High & High & $\begin{array}{c}\text { None } \\
\text { (impossible to } \\
\text { get used) }\end{array}$ \\
\hline $\begin{array}{l}\text { Efficiency (number of trees } \\
\text { treated with one charged battery) }\end{array}$ & About 30 & About 180 & - \\
\hline $\begin{array}{l}\text { Duration of a fully } \\
\text { charged battery }\end{array}$ & $\begin{array}{c}\text { Approximately } \\
\text { one hour }\end{array}$ & $\begin{array}{c}\text { Approximately } \\
\text { six hours }\end{array}$ & - \\
\hline Working speed & $\begin{array}{c}\text { The highest } \\
\text { (over small areas) }\end{array}$ & High & $\begin{array}{c}\text { High } \\
\text { (only near } \\
\text { electrical supply) }\end{array}$ \\
\hline
\end{tabular}

stems. By contrast, the second method, consisting of a fully charged car battery connected to an inverter and to the drill, allowed to drill the remaining 50 trees (10 in the first site and 40 in the second site) before running out of power. As we verified that a fully charged car battery lasts about 6 hours, up to 180 stems could be treated with a single battery recharge (Tab. 2).

\section{Discussion}

Effective methods for controlling A. altissima are urgently needed all around the world and should be immediately implemented, especially into woodlands and other forested sites heavily invaded by this fast-growing tree. Previous studies concerning the control of A. altissima by stem-injection of herbicides (Burch \& Zedaker 2003, Meloche \& Murphy 2006, DiTomaso \& Kyser 2007, Constán- Nava et al. 2010, Bowker \& Stringer 2011) do not provide detailed information on which application methods are practical and actually feasible in the field. In this work, we applied an effective and simple way to clear Ailanthus-infested areas also in faraway, hardly-accessible, rugged locations, as in many forest sites in southern Italy.

We have chosen to use the glyphosate - a non-selective systemic herbicide - because of its effectiveness in other control trials concerning A. altissima (e.g., Constán-Nava et al. 2010), and we chose stem-injection technique because it can be applied to many trees in fairly short time, minimizing the quantity of required herbicide (DiTomaso \& Kyser 2007, Meloche \& Murphy 2006). In other experiments, glyphosate has also been used to fill the cut in trunks caused by "machete" (Buddenhagen et al. 2004), while in Palermo city (Sicily) local gardeners are used to control Ailanthus-infested sites by injecting glyphosate in holes created by drill.

Herbicide injection has to be carried out very carefully, as glyphosate may cause skin or eyes irritation after direct exposure in humans, and also some animal species, in particular amphibians and fishes, are susceptible to poisoning (Bradberry et al. 2004, Howe et al. 2004, Ayoola 2008, Relyea \& Jones
2009). This is particularly true for some glyphosate-based herbicide, which are specifically toxic in aquatic environments. However, in terrestrial ecosystems glyphosate has low mobility, as it is rapidly adsorbed by soil colloids and eventually inactivated by microbial degradation (Schuette 1998, Busse et al. 2001). For this reason, glyphosate is one of the most commonly used herbicides in natural areas (Tu et al. 2001 - see also references therein). To prevent any possible environmental risk, stem injection joined with the subsequent cover of the drilled holes is the safest technique to be used in natural habitats or in areas to be preserved. Our experiments confirmed that glyphosate injection could be a safe method of control even in presence of native significant species.

According to DiTomaso \& Kyser (2007), we found that the application rate of $1 \mathrm{~mL}$ of glyphosate per tree is effective when DBH is $<8 \mathrm{~cm}$, but $2 \mathrm{~mL}$ is needed when $\mathrm{DBH} \geq 8$ $\mathrm{cm}$. Our results are consistent with other researches which provided a high mortality of plants treated by stem-injection or with the EZ-Ject ${ }^{\circledR}$ application system (Meloche \& Murphy 2006, DiTomaso \& Kyser 2007, Bowker \& Stringer 2011), also in the case where sprouts following a cut-stump treatment (Harrington \& Miller 2005, Meloche \& Murphy 2006, DiTomaso \& Kyser 2007, Constán-Nava et al. 2010).

Although previous studies demonstrated that herbicide is best applied via holes drilled into the stem (e.g., DiTomaso \& Kyser 2007), the electrical source to power the drill was not previously taken into consideration. Use of the electrical drill is only feasible when the electrical supply is close to the interventions areas, though the presence of long electrical cables in the field is unsafe, mainly when the terrain is rough or steep. Generators are quite efficient but are usually heavy to be carried and thus are suitable only for treating small and easily-accessible areas. A cordless drill would be the best solution, but the batteries usually cannot supply adequate power; its use is therefore discouraged unless the unit can be readily recharged or treatment has to be applied to few trees. Based on our field trials, we recommend the use as power supply of a fully charged car battery (usually delivering a peak current of 450 A). Car batteries are relatively light, can therefore be readily moved to different locations in the field, and can be used with short cables. Although they are heavier than a cordless drill, car batteries are able to supply power for a much longer time (see Tab. 2) and so they should be suitable for Ailanthus control in natural settings, over wide areas and on hillsides. As for the drill regards bits, $10-\mathrm{cm}$-long and $10 \mathrm{~mm}$-diameter helical bits enable to drill holes quickly and with little effort.

\section{Conclusion}

In conclusion, invasion by A. altissima is a serious problem all around the world, and calls for suitable solutions to hinder its unobstructed spread. Although injection of glyphosate (and of other herbicides) into holes drilled into stems kills the trees, a power supply is needed for the drill, and obtaining electrical power in remote areas can be difficult. We think that our technique could be readily applied in the field, not only in suburban areas but also in natural areas such as forests and other woodlands.

\section{Acknowledgments}

The research was performed under the Agreement with the Department of Agriculture and Forestry of the Sicilian Region: "Analisi dei sistemi seminaturali e degli agro ecosistemi nei sistemi insulari mediterranei: Isola di Lampedusa, pantani di Vendicari e sistemi agricoli regionali ad Alto Valore Naturale (AVN)". We thank Giuseppe La Mantia, John J. Borg, Salvatore Pasta and Davide Molone for their assistance.

\section{References}

Affre L, Suehs CM, Charpentier S, Vilà M, Brundu G, Lambdon P, Traveset A, Hulme PE (2010). Consistency in the habitat degree of invasion for three invasive plant species across Mediterranean islands. Biological Invasions 12: 2537-2548. - doi: 10.1007/s10530-009-9662-6 Anonymous (2012). Tree of heaven. The Invasive Plant Atlas of the United States, no. 309. [online] URL: http://www.invasiveplantatlas.org/ subject.html?sub=3003

Ayoola SO (2008). Toxicity of glyphosate herbicide on Nile tilapia (Oreochromis niloticus) juvenile. African Journal of Agricultural Research 3 (12): 825-834. [online] URL: http://www.academicjournals.org/ajar/pdf/pdf\%202008/Dec/Ayoola.pdf Badalamenti E, Barone E, Pasta S, Sala G, La Mantia T (2012). Ailanthus altissima (Mill.) Swingle (fam. Simaroubaceae) in Sicilia e cenni storici sulla sua introduzione in Italia (Ailanthus altissima (Mill.) Swingle (fam. Simaroubaceae) in Sicily and historical remarks on its introduction in Italy). Naturalista siciliano S. IV, 36 (1): 
117-164.

Basnou C, Vilà M (2009). Ailanthus altissima (Mill.) Swingle, tree of heaven (Simaroubaceae, Magnoliophyta). In: "Handbook of alien species in Europe" (DAISIE ed). Springer, Dordrecht The Netherlands, pp. 342.

Blair MP, Zedaker SM, Seiler JR, Hipkins PL, Burch PL (2006). Evaluation of rapid screening techniques for woody plant herbicide development. Weed Technology 20: 971-979. - doi: 10.1614/WT-05-123.1

Bowker D, Stringer J (2011). Efficacy of herbicide treatments for controlling residual sprouting of tree-of-heaven. In: Proceedings of the " $17^{\text {th }}$ Central Hardwood Forest Conference" (Fei S, Lhotka JM, Stringer JW, Gottschalk KW, Miller GW eds). Lexington (KY, USA) 5-7 April 2010. Northern Research Station, USDA Forest Service, pp. 128-133.

Bradberry SM, Proudfoot AT, Vale JA (2004). Glyphosate poisoning. Toxicological Reviews 23 (3): 159-167. - doi: 10.2165/00139709-200423 030-00003

Buddenhagen CE, Renteria JL, Gardener $\mathrm{M}$, Wilkinson SR, Soria M, Yánez P, Tye A, Valle $\mathrm{R}$ (2004). The control of a highly invasive tree Cinchona pubescens in Galapagos. Weed Technology 18: 1194-1202. - doi: 10.1614/0890037X(2004)018[1194:TCOAHI]2.0.CO;2

Burch PL, Zedaker SM (2003). Removing the invasive tree Ailanthus altissima and restoring natural cover. Journal of Arboriculture 29: 18-24. [online] URL: http://www.utilityarborist.org/images/Historical\%20Articles/JOA\%20Jan03.pdf

Busse MD, Ratcliff AW, Shestak CJ, Powers RF (2001). Glyphosate toxicity and the effects of long-term vegetation control on soil microbial communities. Soil Biology \& Biochemistry 33: 1777-1789. - doi: 10.1016/S0038-0717(01)001 03-1

Capuana M (2011). Heavy metals and woody plants - biotechnologies for phytoremediation. iForest 4: 7-15. - doi: 10.3832/ifor0555-004 Celesti-Grapow L, Blasi C (2004). The role of alien and native weeds in the deterioration of archaeological remains in Italy. Weed Technology 18: 1508-1513. - doi: 10.1614/0890-037X(2004) 018[1508:TROAAN]2.0.CO;2

Celesti-Grapow L, Pretto F, Carli E, Blasi C (2010). Flora vascolare alloctona e invasiva delle regioni d'Italia. Casa Editrice Università La Sapienza, Roma, Italy, pp. 208.

Constán-Nava S, Bonet A, Pastor E, Lledo $\mathrm{M}$ (2010). Long-term control of the invasive tree Ailanthus altissima: insights from Mediterranean protected forests. Forest Ecology and Management 260: 1058-1064. - doi: 10.1016/j.foreco. 2010.06.030

DiTomaso JM, Kyser GB (2007). Control of Ail- anthus altissima using stem herbicide application techniques. Arboriculture and Urban Forestry 33: 55-63.

DiTomaso JM, Brooks ML, Allen EB, Minnich R, Rice PM, Kyser GB (2006). Control of invasive weeds with prescribed burning. Weed Technology 20: 535-548. - doi: 10.1614/WT-05-086R1. 1

Drago A, Lo Bianco B, Monterosso I (2002). Atlante climatologico della Sicilia. Assessorato Agricoltura e Foreste, Servizio Informativo Agrometereologico Siciliano, Regione Siciliana, $\mathrm{Pa}-$ lermo, Italy.

Graves WR, Joly RJ, Dana MN (1991). Water use and growth of honey locust and tree of-heaven at high root-zone temperature. HortScience 26: 1309-1312. [online] URL: http://hortsci.ashspublications.org/content/26/10/1309.full.pdf+ht $\mathrm{ml}$

Harrington TB, Miller JH (2005). Effects of application rate, timing, and formulation of Glyphosate and Triclopyr on control of Chinese Privet (Ligustrum sinense). Weed Technology 19: 47-54. - doi: 10.1614/WT-03-220R2

Hoshovsky MC (1988). Element stewardship abstract for Ailanthus altissima., The Nature Conservancy, Arlington, VA, USA. [online] URL: http://www.invasive.org/gist/esadocs/documnts/a ilaalt.pdf

Howe CM, Berrill M, Pauli BD, Helbing CC, Werry K, Veldhoen N (2004). Toxicity of glyphosate-based pesticides to four North American frog species. Environmental Toxicology and Chemistry 23 (8): 1928-1938. - doi: 10.1897/0371

Knapp LB, Canham CD (2000). Invasion of an old-growth forest in New York by Ailanthus altissima: sapling growth and recruitment in canopy gaps. Journal of The Torrey Botanical Society 127: 307-315. - doi: 10.2307/3088649

Kowarik I, Säumel I (2007). Biological flora of central Europe: Ailanthus altissima (Mill.) Swingle. Perspectives in Plant Ecology, Evolution and Systematics 8: 207-237. - doi: 10.1016/ j.ppees.2007.03.002

Lambdon PW, Pyšek P, Basnou C, Hejda M, Arianoutsou M, Essl F, Jarošík V, Pergl J,Winter M, Anastasiu P, Andriopoulos P, Bazos I, Brundu G, Celesti-Grapow L, Chassot P, Delipetrou P, Josefsson M, Kark S, Klotz S,KokkorisY, Kühn I, Marchante H, Perglová I, Pino J,Vilà M, Zikos A, Roy D, Hulme PE (2008). Alien flora of Europe: species diversity, temporal trends, geographical patterns and research needs. Preslia 80: 101-149. [online] URL: http://www.preslia.cz/P082Lam.pdf

Meggaro Y, Vilà M (2002). Distribución y regeneración después del fuego de dos especies exóticas Ailanthus altissima y Robinia pseudoacacia en el Parque de Collserola (Barcelona). Montes 68: 25-33.

Meloche C, Murphy SD (2006). Managing treeof-heaven (Ailanthus altissima) in parks and protected areas: a case study of Rondeau Provincial Park (Ontario, Canada). Environmental Management 37: 764-772. - doi: 10.1007/s00267-0030151-x

Relyea RA, Jones DK (2009). The toxicity of Roundup Original Max ${ }^{\circledR}$ to 13 species of larval amphibians. Environmental Toxicology and Chemistry 28 (9): 2004-2008. - doi: 10.1897/09021.1

Requardt A, Schuck A, Köhl M (2009). Means of combating forest dieback - EU support for maintaining forest health and vitality. iForest 2: 38 42. - doi: 10.3832/ifor0480-002

Schuette J (1998). Environmental fate of glyphosate. Environmental Monitoring and Pest Management, Dept. of Pesticide Regulation, Sacramento, CA, USA. [online] URL: http://www.cdpr.ca.gov/docs/emon/pubs/fatememo/glyphos.pdf

Traveset A, Brundu G, Carta M, Mprezetou I, Lambdon P, Manca M, Médail F, Moragues E, Rodriguez-Perez J, Siamantziouras S, Suehs CM, Troumbis A, Vilà M, Hulme PE (2008). Consistent performance of invasive plant species within and among islands of the Mediterranean basin. Biological Invasions 10: 847-858. - doi: 10.1007/s10530-008-9245-y

Trifilò P, Raimondo F, Nardini A, Lo Gullo MA, Salleo S (2004). Drought resistance of Ailanthus altissima: root hydraulics and water relations. Tree Physiology 24: 107-114. - doi: 10.1093/ treephys/24.1.107

Tu M, Hurd C, Randall JM, The Nature Conservancy (2001). Weed control methods handbook: tools and techniques for use in natural areas. Report no. 533, Utah Regional Depository, U.S. Government Documents, Utah State University, USA. [online] URL: http://digitalcommons.usu.edu/govdocs/533

Vilà M, Tessier M, Suehs CM, Brundu G, Carta L, Galanidis A, Lambdon P, Manca M, Médail F, Moragues E, Traveset A, Troumbis AY, Hulme PE (2006). Local and regional assessment of the impacts of plant invaders on vegetation structure and soil properties of Mediterranean islands. Journal of Biogeography 33: 853-861. doi: 10.1111/j.1365-2699.2005.01430.x

Vilà $M$, Siamantziouras A-SD, Brundu G, Camarda I, Lambdon P, Médail F, Moragues E, Suehs CM, Traveset A, Troumbis AY, Hulme PE (2008). Widespread resistance of Mediterranean island ecosystems to the establishment of three alien species. Diversity and Distributions 14: 839-851. - doi: 10.1111/j.1472-4642.2008.005 03. 